\title{
Digital Technologies as a Tool for Improving Publicity of the State Sector
}

\author{
Nadiya Mikhailovna Sabitova \\ Department of financial markets and financial institutions \\ Kazan (Volga region) Federal University, Institute of \\ Administration, Economics and Finance \\ Kazan, Russia \\ sabitovanm@mail.ru
}

\author{
Chulpan Mansurovna Shavaleyeva \\ Department of financial markets and financial institutions \\ Kazan (Volga region) Federal University, Institute of \\ Administration, Economics and Finance \\ Kazan, Russia \\ chulpan212@mail.ru
}

\author{
Elena Vladimirovna Bolonina \\ Department of financial markets and financial institutions \\ Kazan (Volga region) Federal University, Institute of \\ Administration, Economics and Finance \\ Kazan, Russia \\ alenyshka1983@mail.ru
}

Elena Nikolaevna Lizunova

Department of financial markets and financial institutions Kazan (Volga region) Federal University, Institute of Administration, Economics and Finance Kazan, Russia elnik-fin@mail.ru

\begin{abstract}
The article discusses the experience of the Russian Federation and foreign countries in the introduction of digital technologies in the state financial sector. The active automation of all processes related to budgetary activities by the countries is caused by the tendency to increase its level of publicity and transparency for the society, as well as by saving budget funds and increasing the efficiency of the use of budget resources. The review of information systems of state sector management in different countries revealed the main General areas in which the introduction of digital technologies is most justified and effective: as a rule, these are subsystems of revenue accounting, budget expenditures, as well as control systems for state-owned corporation and the formation of an accessible and understandable "Budget for citizens". The possible directions of exchange of experience between the countries allowing to reach faster the main goal of digitalization of the budgetary sphere increase of budgetary publicity and transparency in each country are revealed.
\end{abstract}

Keywords: public finance, digital technologies, budget, state sector, budget publicity, budget transparency, electronic budget

\section{INTRODUCTION}

Modern financial technologies have become widely used in Russia and in the state sector, in particular. These technologies are being implemented in the activities of both Federal and regional financial authorities, as well as ministries and departments, as recipients of budget funds. The Ministry of Finance of the Russian Federation and the Federal Treasury under its jurisdiction, the Federal tax service and other services are also actively involved in the process of introducing digital technologies into their activities. The most successful in this work is the Federal tax service, which effectively uses information technology to identify tax violations. The Federal Treasury is also quite successful in implementing information technology in its work, in particular, the information and analytical system of the Federal Treasury, which is a system of collection, analysis and visualization of operational data and includes an information and analytical system for monitoring key performance indicators of the funds of the budget system of the Russian Federation, a system for monitoring and analysis of state and municipal procurement and other data. Back in 2011, the decree of the government of the Russian Federation (dated 20.07.2011 No. 1275-p) approved the "Concept of creation and development of the state integrated information system of public Finance management "Electronic budget"", which is now successfully functioning [1]. The Ministry of Finance of the Russian Federation is also actively engaged in the issues of Informatization in the framework of the project "open Ministry", in which all ministries are involved. The concept of publicity of Federal Executive authorities was approved by the order of the Government of the Russian Federation in January 2014 [2]

The introduction of information technology is currently addressing not only the efficiency of the budget system of the Russian Federation, but also aimed at ensuring transparency in the budget sector, ensuring the confidence of citizens in the authorities. 


\section{METHODS}

The issues of digital economy in the state sector are shown in the publications of foreign authors on various aspects. Thus, authors Guo Xiaomei and Yang Qi investigate the integration of information systems with the budget control system: digitalization provides parties concerned with realtime information and increases the efficiency of decisionmaking [3]. Effah John and Nuhu Hubeidatu analyze institutional barriers to the digitalization of state budgets in developing countries: outdated laws and a paper-based flow of documents, a lack of an integrated approach to the implementation of the system, and inadequate and unreliable online access for all participants are the main obstacles to the digitalization of state budgeting [4]. The authors Liu Chen, Han Qiao-chu, Yu Dian-qing studied some issues of the budget process, namely information technologies of state procurement implementation: the principles of supplier evaluation, procurement schedule management, financial reporting analysis based on network remote interaction technology are proposed [5]. Naseer, M. A., Bimal, P., Kumar, T. M. Vinod represent the possibility of developing an electronic municipal budget taking into account feedback from citizens, or the so-called "participatory" budget, in order to make joint budget decisions with the population for the most rational distribution of funds [6]. Russian authors Dolganova Y., Istomina N., Terentyeva M. explore the current trends of digitalization of economic processes in the context of economic sectors; systematize scientific provisions on the advantages of digital technologies; generalize the existing practices of regulation of digital processes in the Russian Federation at the state level [7]. Tolmachova O., Lvova M., Salamatina Y. analyze approaches to the regulation of the development of digitalization of Finance in the regional context [8].

Technological progress and the global digitalization of all spheres of life also required the transformation of budgetary legal relations, taking into account the increasing importance of the principles of efficiency, economy, convenience, publicity and transparency. The one of leading importance in the company's assessment of budget activity is principle of transparency, which in accordance with the Budget Code of the Russian Federation means mandatory publication in the mass media of budgets and reports on their execution, completeness of information on the progress of budget execution,; mandatory publicity to the public and the media of draft budgets; providing access to information posted in the information and telecommunication network "Internet" on the budget system portal of the Russian Federation, etc. [9].

Internationally, since 2006, the International Budget Partnership has been assessing the transparency of national budgets. Thus, for 9 years of analysis, the index of publicity of the Russian budget rose from "insufficient level" of 47 points to 74 points, which corresponds to the characteristic of publicity as a "significant level". According to the latest assessment, Russia ranks 11th among the 102 countries participating in the survey [10]. Such recognition by an independent organization of the level of transparency of the Russian budget testifies to positive changes in the budget management, a key role in which belongs to the creation and implementation the state information system "Electronic budget" in the practice of budget activities. [11].

More than 50 countries worldwide have digitalized the system of budget management. Models of information systems of some countries and the Russian Federation were chosen as the object of research.

\section{RESULTS}

Information on the main models of information systems and their functional characteristics in some countries is presented in table 1 .

TABLE I. MODELS OF BUDGET MANAGEMENT INFORMATION SYSTEMS IN SOME COUNTRIES

\begin{tabular}{|c|c|c|c|}
\hline $\begin{array}{c}\text { Countr } \\
y\end{array}$ & System & $\begin{array}{c}\text { Year of } \\
\text { implem } \\
\text { entatio } \\
n\end{array}$ & Functional characteristics (subsystems) \\
\hline France & Chorus & 2010 & $\begin{array}{l}\text { The programs of the ministries and their } \\
\text { territorial authorities (about } 150 \text { programs) are } \\
\text { implemented in a unified system }[12,13] \text {. } \\
\text { System architecture: } \\
\text { - state revenue management; } \\
\text { - cost management; } \\
\text { - government accounting and reporting; } \\
\text { - government debt management; } \\
\text { - procurement management; } \\
\text { - book-keeping. }\end{array}$ \\
\hline $\begin{array}{l}\text { SouthK } \\
\text { orea }\end{array}$ & $\begin{array}{l}\text { FMIS } \\
\text { dBrain }\end{array}$ & $\begin{array}{l}2000- \\
2006 \\
2007\end{array}$ & $\begin{array}{l}\text { Information system that allows accurate cash } \\
\text { flow projection, to which all ministries are } \\
\text { connected; includes } 21 \text { modules [14]. Automatic } \\
\text { integration with } 41 \text { external information } \\
\text { systems. } \\
\text { System architecture: } \\
\text { - budget planning; } \\
\text { - project management; } \\
\text { - disbursements; } \\
\text { - receipts; } \\
\text { - book-keeping; } \\
\text { - liquidity control. }\end{array}$ \\
\hline Brazil & $\begin{array}{l}\text { SIAFI } \\
\text { SIOP } \\
\text { SIASG } \\
\text { NetSiCo } \\
\text { nv } \\
\text { SIAPE } \\
\text { SISAC }\end{array}$ & 1987 & $\begin{array}{l}\text { Integrated information system of Federal budget } \\
\text { management, including: } \\
\text { SIAFI-basic Treasury information system; } \\
\text { SIOP-investment planning and budget } \\
\text { preparation system; } \\
\text { SIASG Net-procurement management system; } \\
\text { SiConv - system of conducting inter-budgetary } \\
\text { agreements (pacts) between the Federation and } \\
\text { the subjects of the Federation; } \\
\text { SIAPE-HR management system and payroll } \\
\text { database; } \\
\text { SISAC-audit support system [15] }\end{array}$ \\
\hline Russia & $\begin{array}{l}\text { E- } \\
\text { budget }\end{array}$ & 2015 & $\begin{array}{l}\text { A unified software product that can be used by } \\
\text { all participants of the budget process through the } \\
\text { Internet [16]. } \\
\text { System architecture: } \\
\text { - budget system (structure, legal form of } \\
\text { budgets, stages and participants of the budget } \\
\text { process); } \\
\text { - budget (receipts, disbursements, balance, state } \\
\text { support, state investments, state programs, state } \\
\text { debt, quality of financial management of the } \\
\text { chief administrators of budget funds); } \\
\text { - regions (social, financial and economic state of } \\
\text { regions); } \\
\text { - state sector (information on the activities of } \\
\text { state administration organizations in the field of } \\
\text { public finance management); } \\
\text { - data and services (book-keeping, analytical and } \\
\text { communication services) }\end{array}$ \\
\hline
\end{tabular}


Thus, the desire for publicity and transparency of the budget through the creation of information systems do not depend on the type of government or the level of economic development - the creation of such systems is observed in both developed (France) and developing countries (South Korea, Brazil). According to The World Bank, the most comprehensive information systems of state finance management are the digital systems of South Korea and Brazil, while there are no analogues of the "Electronic budget" system implemented in Russia in terms of scale and technology in the world.

In the Russian Federation, the project "Electronic budget" was introduced on a phased basis, since 2011, and actively began to be used since 2016, the trends of access to databases are presented in Fig.1.

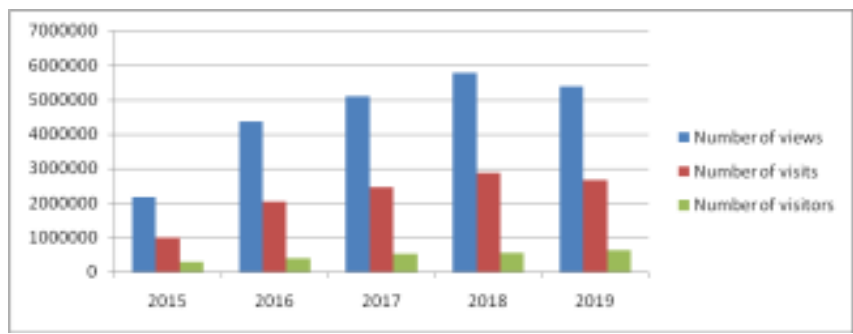

Fig. 1. Statistics on the use of the "Electronic budget" system in the Russian Federation

According to the website "Electronic budget" there is a constant increase in the number of visitors, and hence the popularity of the system among users. Among the advantages of the Russian information system are the following:

- access to the portal in real time: all parties concerned can be informed about government spending in various activities;

- transition from local data collection and storage systems to General data storage systems: simplification and acceleration of document flow;

- ability to plan and execute the budget together with subordinate organizations in a unified database;

- reduction of data entry errors by eliminating the need for multiple input of information and the use of a common methodology for all planning and budget execution;

- automation of document processing and control over their execution;

- the system architecture allows to provide comparability of information and possibility of its use by all participants on the basis of electronic forms [17].

\section{DISCUSSION}

The "Electronic budget" system interacts very closely with other information systems - for example, the state information system on governmental and municipal payments, the information and analytical system of the Federal Treasury, the automated information system "Management", the official website for posting information about governmental and municipal institutions, etc. Therefore, it can be concluded that in the field of public Finance there is no single structured information system that allows you to logically and consistently trace the mechanism of functioning of information resources in the form of a clear and coherent design [18]. However, this conclusion applies equally to the information systems of foreign countries (table.1). Further integration, unification and simplification of databases is a General trend in the development of information systems of the budget sector.

The experience of the Russian Federation in creating a budget calculator for citizens may be of interest to improve the foreign practice of using digital technologies in the state sector [19]. The main purpose of the budget calculator is to increase the budget literacy of the population and the development of a constructive dialogue between the government and society on budget issues. Any citizen just by clicking on the link may simulate one's own version of the budget of the subject of the Russian Federation or a municipal government, to discuss the draft budget for the next fiscal year, the approved budget and budget execution for the previous year. The availability of information does not mean its transparency and publicity, its presentation in a language understandable to society can form a constructive and interested position of citizens in relation to the state and public finances. In world practice, according to the recommendations of the International budget partnership, so-called "budgets for citizens" are also created, which contain accessible information about the main characteristics of budget policy. However, there is no feedback, which is fully implemented in the tool "Budget calculator for citizens".

Experience of Brazil in terms of expanding the mechanisms of information participation of the public in the budget process, and strengthening the so-called principles of "participatory" will also be of interest for Russia, as part of the further improvement of the information system "Electronic budget"

In conclusion, it can be noted that in the Russian Federation, the process of introducing digital technologies in the budget and tax sphere continues, while information technologies are changing and improving quite quickly. The main task of implementing these technologies is to ensure the efficiency of the budget system of the Russian Federation, including improving the quality of financial management in the budget sphere, effective management of limited budget resources, quality monitoring of the activities of all participants in the budget process, as well as effective interaction with them. At the same time, the direction of budget publicity for citizens should continue to develop, which would increase public interest in budget issues. At present, the public interest in these issues, judging by the statistics of appeals, in our opinion, is insufficient.

\section{References}

[1] "About approval of the Concept of creation and development of the state integrated information system of management of public finances "the Electronic budget", The decree of the Government of the Russian Federation, no. 1275-r, 20 July 2011 [Electronic resource]. Available at: http://docs.cntd.ru/document/902291021 (Accessed: 20.12.2019). 
[9] The budget code of the Russian Federation, no. 145-FL, 31 July 1998 [Electronic source]. Available at: the legal reference system "Consultant-plus".

[2] "About the statement of the Concept of openness of Federal Executive authorities", The decree of the Government of the Russian Federation, no. 93, 30 January 2014 [Electronic source]. Available at: http://docs.cntd.ru/document/499073612 (Accessed: 20.12.2019).

[3] X. Guo and Qi Yang, "On the Integration of IT System with the Budgetary Control System: Insights from the Case of Wanhua Chemical", Wireless personal communications, t. 102, vol. 4, p. 36873697, October 2018.

[4] J. Effah and H. Nuhu, "Institutional barriers to digitalization of government budgeting in developing countries: a case study of ghana", Electronic journal of information systems in developing countries, t. 82, vol. 1, no. 5, September 2017.

[5] C. Liu, Qiao-chu Han, and Dian-qing Yu, "The Government Procurement Management System Based on. Net Remoting Technology", 5th International Conference on Machinery, Materials and Computing Technology, ICMMCT, Beijing, PEOPLES R China.: 25-26 March 2017, Proceedings of the 2017 5th international conference on machinery, materials and computing technology, icmmct 2017, Series: AER-Advances in Engineering Research, vol. 126, pp. 670-675, 2017

[6] M.A. Naseer, P. Bimal, and T.M. Kumar, "Vinod.Participatory EBudgeting Using GIS-Based Spatial Decision Support System: Kozhikode Municipal Corporation", E-governance for smart cities: Advances in 21st Century Human Settlements, pp. 307-350, 2015.

[7] Yu.S. Dolganova, N.A. Istomina, and M.N. Terentieva, "Approaches to the Regulation of the Development of Digitalization of Finance in the Regional Economy", 1st International Scientific Conference on Modern Management Trends and the Digital Economy - From Regional Development to Global Economic Growth, MTDE, Inst. Int. Relat., Yekaterinburg, Russia, 14-15 April 2019, t. 81, pp. 268-272, 2019.

[8] O.V. Tolmacheva, M.I. Lvova, and Ya.V. Salamatina, "Tools of state borrowings at the regional level in the digitalization of the economy", 1st International Scientific Conference on Modern Management Trends and the Digital Economy - From Regional Development to Global Economic Growth, MTDE, Location: Inst Int Relat, Yekaterinburg, Russia Published.: 14-15 April 2019, vol. 81, pp. 1-5, 2019.

[10] "A guide to the open budget questionnaire", International budget partnership [Electronic resource]. Available at: https://www.internationalbudget.org/wp-content/uploads/OBS 2015-Questionnaire-and-Guidelines-Russian.pdf

(Accessed: 20.12.2019).

[11] "About the state integrated information system of management of public finances "the Electronic budget", The resolution of the government of the Russian Federation, no. 658, 30 June 2015 [Electronic resource]. Available at: http://base.garant.ru/71123400/ \#block_1000\#ixzz3mNCiwy9g (Accessed: 20.12.2019).

[12] "Chorus", financial budget and accounting management tool in LOLF mode [Electronic resource]. Available at: https://www.performancepublique.budget.gouv.fr/cadre-gestion-publique/cadre-gestionbudgetaires/essentiel/systemes-d-information-financiere-etat/chorusoutil-gestion-financiere-budgetaire-comptable-en-modelolf\#.Xf5O8iMudPY (Accessed: 20.12.2019).

[13] Agency of state financial institutions of France [Electronic resource]. Available at: https://aife.economie.gouv.fr (Accessed: 20.12.2019).

[14] S.E. Prokofiev, "Innovation in public financial management in the Republic of Korea”, Budget, pp. 59-63, November 2014 (in Russian).

[15] International experience in expanding the existing capabilities of Treasury information systems and their integration with external information systems [Electronic resource]. Available at: http://roskazna.ru/ (Accessed: 20.12.2019).

[16] "Electronic budget", SIIS [Electronic resource]. Available at: http://budget.gov.ru/epbs/faces/page_home?_adf.ctrl-state=13s9ts 805m_4. (Accessed: 20.12.2019).

[17] N.M. Zakharova, "Electronic budget: significance and development trends", Integrated information system of public Finance management, Economy, Taxation, Right, vol. 11, no. 2, pp. 155-165, 2018.

[18] N.A. Povetkina, "Legal form of integration of information systems and information technologies in the sphere of public Finance", Journal of Russian law, no. 5, pp. 96-112, 2018.

[19] Budget calculator for citizens [Electronic resource]. Available at: http://citizens-budget.ru/podrobnee-o-byudzhetnom-kalkulyatore. 